\title{
Contamination from an affluent of Furnas reservoir by trace metals
}

\author{
Cavalcanti, PP. ${ }^{a *}$, Rodrigues, LCA. ${ }^{a}$, Beijo, LA. ${ }^{b}$, Barbosa, S. ${ }^{a}$, Xavier, TT. ${ }^{c}$ and Magalhães, $F^{d}$ \\ ${ }^{\text {a}}$ Laboratório de Biotecnologia Ambiental \& Genotoxicidade, Instituto de Ciências da Natureza - ICN, Universidade \\ Federal de Alfenas - UNIFAL-MG, Rua Gabriel Monteiro da Silva, 700, Centro, CEP 37130-000, Alfenas, MG, Brazil

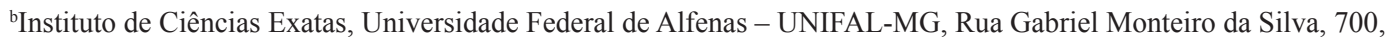 \\ Centro, CEP 37130-000, Alfenas, MG, Brazil \\ 'Instituto de Química, Universidade Federal de Alfenas - UNIFAL-MG, Rua Gabriel Monteiro da Silva, 700, Centro, CEP \\ 37130-000, Alfenas, MG, Brazil \\ dDepartamento de Química, Universidade Federal de Lavras - UFLA, Campus Universitário, CP 3037, CEP 37200-000, \\ Lavras, MG, Brazil \\ *e-mail: portyapc@gmail.com
}

Received: May 2, 2013 - Accepted: June 11, 2013

(With 4 figures)

\begin{abstract}
This study aims to determine concentrations and characterize trace metals distribution in an affluent of Furnas reservoir, Alfenas-MG. Water and sediment samples were taken monthly, 2010/10-2011/07 in five sites of Córrego do Pântano for subsequent determination of $\mathrm{Pb}, \mathrm{Cd}$ and $\mathrm{Zn}$ levels by chemical analysis. The stream studied is in disagreement with Brazilian legislation for Class II water bodies (CONAMA 357). The highlights are the unsuitable concentrations of Pb for human consumption, according to Ministry of Health 2914 decree, providing risk for population.
\end{abstract}

Keywords: lead, cadmium, zinc, river water, human consumption.

\section{Contaminação de um afluente do Reservatório de Furnas por metais traço}

\section{Resumo}

Este trabalho objetiva determinar as concentrações e caracterizar a distribuição de metais traço em um afluente do Reservatório de Furnas, em Alfenas-MG. Foram coletadas amostras de água e sedimento de Outubro de 2010 a Julho de 2011 em cinco pontos do Córrego do Pântano para posterior determinação dos níveis de $\mathrm{Cd}, \mathrm{Pb}$ e $\mathrm{Zn}$ através da análise química. O córrego estudado encontra-se em desacordo com a legislação brasileira para corpos de água Classe II (CONAMA 357). Destacam-se as concentrações de Pb inadequadas para consumo humano, conforme a portaria $\mathrm{n}^{\circ}$ 2914 do Ministério da Saúde, oferecendo risco à população.

Palavras-chave: chumbo, cádmio, zinco, afluente, consumo humano.

\section{Introduction}

Human activities and uncontrolled population growth are responsible for serious environmental pollution problems, for example, the release of domestic and industrial effluents in aquatic environments (Campanha et al., 2010). The increasing industrial development releases a variety of xenobiotics into the environment that cause damage to plant and animal life.

In addition to the effluents, Bollmann and Marques (2006) report that part of the pollution generated in urban areas comes from the solubilization of atmospheric contaminants in stormwater runoff on impervious areas and drainage networks.

Contaminants are indicated as a cause of abnormalities observed in organisms that inhabit aquatic ecosystems, and changes in their population structures. Thus, contaminated aquatic ecosystems have less ability to maintain its self-

depurative processes, causing serious environmental and health problems to the human population (Rocha and Martin, 2005).

Among the various types of contaminants, stand out trace metals, that may be defined as chemical elements found in low concentrations in ecosystems, on the order of parts per million. These metals are often in industrial, urban and agricultural effluents (Lopes, 2006). The environmental impact caused by metals is one of the biggest environmental concerns of today, especially when there is interaction with human populations (Jesus et al., 2004).

In a study of textile effluents that are released into a tributary of Furnas reservoir in Alfenas-MG, was found cytogenotoxicity activity of these samples (Alvim et al., 2011), indicating that water quality of urban streams in this region can be compromised. Therefore, it's necessary 
to perform chemical analyzes of water and sediment of these tributaries to assess the degree of contamination of the environment. So, the aim of this study was to determine and characterize the spatial and temporal distribution of trace metals in the water and sediment from an affluent of Furnas reservoir in Alfenas-MG.

\section{Material and Methods}

\subsection{Study area and sampling}

Water and sediment samples were collected monthly (October 2010 to July 2011, $\mathrm{n}=10$ months) from five sites of Córrego do Pântano, in Alfenas-MG, which receives effluents from two residential neighborhoods and industrial district of the city (Figure 1). The sampling sites represent: (P1) A mine of free access to public supply, coated and covered with masonry, which is the source of the stream (water samples only); (P2) Main sewer junction derived from two residential neighborhood; (P3) Final of disposal urban domestic; (P4) Has urban and industrial wastewater, such as foundry sand and treated liquid effluent from two textile industries; (P5) Adds to contents of P4 the municipal abattoir effluent and the affluent of a second stream, which brings high load of domestic and industrial effluent, passing through the city dump. The mouth of the stream is located in an arm of Furnas reservoir, whose water is used for aquaculture, animal watering, irrigation, primary contact recreation. Due to flooding after the rainy season, collecting sediment from P5 was only possible in the first four months.

Water samples were collected using polyethylene flasks $(500 \mathrm{~mL})$ previously decontaminated in a $\mathrm{HNO}_{3} 10 \%(\mathrm{v} / \mathrm{v})$ solution for 24 hours. The flasks were washed three times with the sampled water and then positioned at approximately $50 \mathrm{~cm}$ from the margin (1-1.5 m width stream) and near the surface of the stream. After collection the samples were acidified $\left(1 \mathrm{~mL} \mathrm{HNO}_{3} / 100 \mathrm{~mL}\right.$ sample) and stored at $4{ }^{\circ} \mathrm{C}$ for a maximum of 24 hours (APHA et al., 2005). With the aid of a nontoxic polyethylene container (1 L), were collected about $2 \mathrm{~kg}$ of sediment per site that were placed in plastic bags (Mitteregger-Júnior et al., 2006). The sediment samples were dehydrated at $45 \pm 2{ }^{\circ} \mathrm{C}$ until it reaches constant weight. Thereafter the dried samples were triturated, standardized in fine mesh $\left(1 \mathrm{~mm}^{2}\right)$ and stored in plastic bags, protected from light and moisture (ABNT, 1987).

\subsection{Chemical analysis - trace metals quantification}

Water and sediment samples were subjected to chemical analysis to determine $\mathrm{Pb}, \mathrm{Cd}$ and $\mathrm{Zn}$ levels. The analysis were made in triplicate and for analytical quality control, were made the whites from MilliQ water, which was subjected to digestion according to the stream sample. Digestion of $50 \mathrm{~mL}$ of liquid samples, previously filtered, was performed with $5 \mathrm{~mL}$ of concentrated $\mathrm{HNO}_{3}$ (P.A.) and $5 \mathrm{~mL} \mathrm{H}_{2} \mathrm{O}_{2}$ (35\% - P.A.). Obtained solutions were heated at $90 \pm 5^{\circ} \mathrm{C}$ until reducing to $10 \mathrm{~mL}$. Digested samples were transferred quantitatively into a $25 \mathrm{~mL}$ volumetric flask and the volume measured with ultrapure water (Santana and Barroncas, 2007). Pb and Cd quantifications were performed by graphite furnace atomic absorption spectrophotometry (GF-AAS, Shimadzu ${ }^{\circledR}$ AA-7000) and $\mathrm{Zn}$ by flame atomic absorption spectrophotometry (F-AAS, Shimadzu ${ }^{\circledR}$ AA-7000), with wavelengths 228.8, 217.0 and $213.9 \mathrm{~nm}$, respectively. Analytical curves used for determining metals in samples were obtained from solutions prepared with $1 \times 10^{3}$ mg. $\mathrm{L}^{-1}\left(\mathrm{Specsol}^{\circledR}\right) \mathrm{Pb}, \mathrm{Cd}$ and $\mathrm{Zn}$ patterns.

Sediment samples were digested using approximately $4 \mathrm{~g}$, which was mixed with $20 \mathrm{~mL}$ of $\mathrm{HCl} / \mathrm{HNO}_{3}(3: 1 \mathrm{v} / \mathrm{v})$ at $90 \pm 5{ }^{\circ} \mathrm{C}$ for $2 \mathrm{~h}$. After the release of fumes, mixture was filtered and quantitatively transferred to a $25 \mathrm{~mL}$ volumetric flask, with volume measured with ultrapure

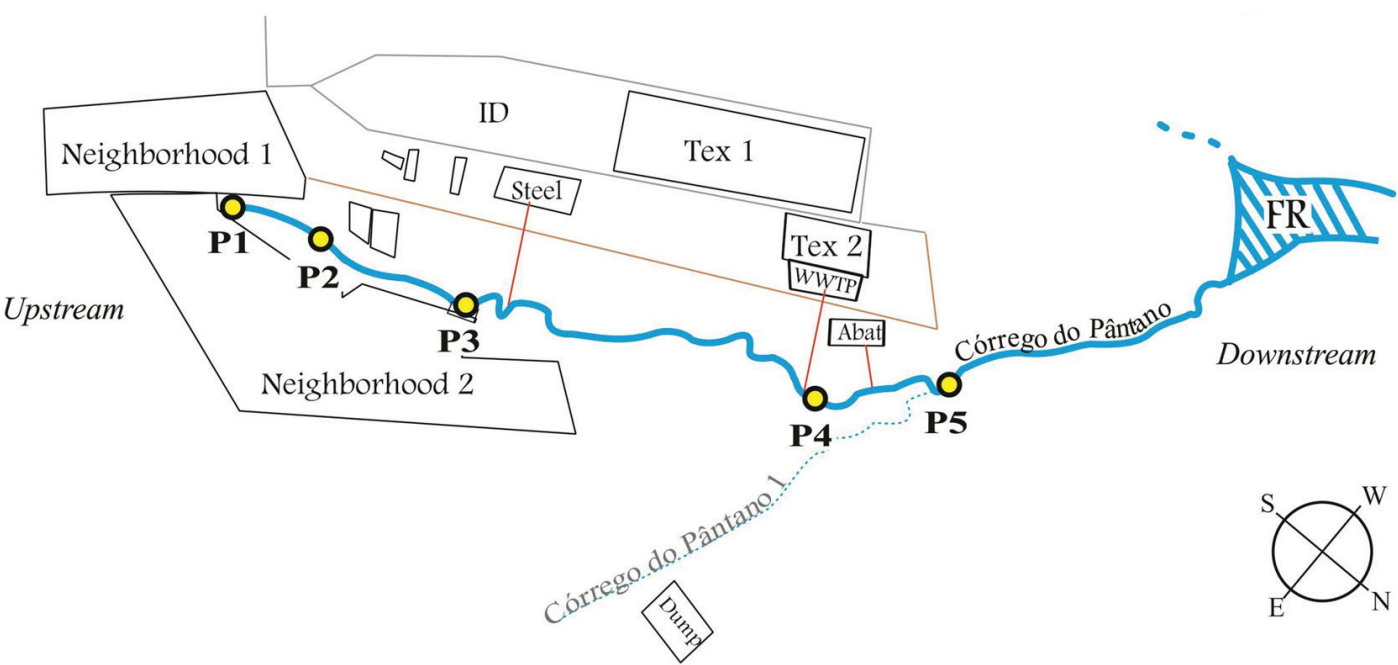

Figure 1. Illustrative map of sampling sites and stream structure until its mouth. ID = Industrial District; Steel = Steel Industry; Abat = Abattoir; Tex $=$ Textile Industry; WWTP $=$ Wastewater Treatment Plant; FR = Furnas reservoir. 
water. The quantification of metals was performed by flame atomic absorption spectrophotometry (F-AAS, Shimadzu AA-7000).

For comparison of chemical analyzes results, were used the quality standards of water bodies Class II (CONAMA, 2005), because the stream wasn't framed in this classification yet. For sediments were adopted quality criteria for Level 1 (CONAMA, 2004), that determine the threshold below which is predicted low probability of adverse effects to biota.

Drinking water must respect potability standards, which set limits on chemical substances that offer health risk, such as metals. Thus, metal concentrations were compared with the maximum allowed by the Ministry of Health (Brasil, 2011).

\subsection{Statistical analysis}

Metals distribution over time in water and sediment samples was analyzed using descriptive statistics and were plotted Box-plot. According to McGill et al. (1978), this graphical analysis allows visualization of the dispersion, the median, the first and third quartiles of data via graphics in boxes forms. Vertical straight lines show the maximum and minimum values observed and the small circles represent extreme observation. It's understood by extreme observation as a point that is distant from the others (Souza, 1998).

In order to check if metals concentrations showed a trend over time, in each site was used Pearson linear correlation and the randomness test (run test) (Siegel and Castellan, 1988). In these analyzes, it wasn't considered site P5 of sediment samples, because it presents data from only four collections.

\section{Results}

In Table 1 are the descriptive statistics for $\mathrm{Pb}, \mathrm{Cd}$ and $\mathrm{Zn}$ concentrations quantified in water samples, Brazilian legislation limits for these metals in water bodies Class II (CONAMA 357) and potability standards for drinking water (Ministry of Health).

Table 1. Descriptive statistics of $\mathrm{Pb}, \mathrm{Cd}$ and $\mathrm{Zn}$ concentrations $\left(\mathrm{mg} \cdot \mathrm{L}^{-1}\right)$ in water samples for each site. CONAMA limits established by $357 / 2005$ resolution (Class II) and maximum allowable values by decree 2914 of Ministry of Health (MH) for metals concentrations in the water.

\begin{tabular}{|c|c|c|c|c|c|}
\hline \multicolumn{6}{|c|}{$\mathbf{P b}$} \\
\hline Site & Average & $\begin{array}{l}\text { Standard } \\
\text { deviation }\end{array}$ & Minimum value & Maximum value & RSD \\
\hline P1 & $0.0381^{\mathrm{ab}}$ & 0.0382 & $<0.005^{\mathrm{DL}}$ & $0.0990^{\mathrm{ab}}$ & $100.38 \%$ \\
\hline $\mathrm{P} 2$ & $0.0452^{\mathrm{ab}}$ & 0.0563 & $<0.005^{\mathrm{DL}}$ & $0.1435^{\mathrm{ab}}$ & $124.56 \%$ \\
\hline P3 & $0.0497^{\mathrm{ab}}$ & 0.0617 & $<0.005^{\mathrm{DL}}$ & $0.1437^{\mathrm{ab}}$ & $124.08 \%$ \\
\hline $\mathrm{P} 4$ & $0.0429^{\mathrm{ab}}$ & 0.0485 & $<0.005^{\mathrm{DL}}$ & $0.1025^{\mathrm{ab}}$ & $112.83 \%$ \\
\hline P5 & $0.0320^{\mathrm{ab}}$ & 0.0443 & $<0.005^{\mathrm{DL}}$ & $0.0991^{\mathrm{ab}}$ & $138.34 \%$ \\
\hline CONAMA & $0.01 \mathrm{mg} . \mathrm{L}^{-1}$ & & & & \\
\hline $\mathrm{MH}$ & $0.01 \mathrm{mg} . \mathrm{L}^{-1}$ & & & & \\
\hline \multicolumn{6}{|c|}{ Cd } \\
\hline Site & Average & $\begin{array}{l}\text { Standard } \\
\text { deviation }\end{array}$ & Minimum value & Maximum value & RSD \\
\hline P1 & $0.0018^{b}$ & 0.0019 & $<0.0005^{\mathrm{DL}}$ & $0.0049^{\mathrm{b}}$ & $106.67 \%$ \\
\hline $\mathrm{P} 2$ & $0.0051^{\mathrm{b}}$ & 0.0071 & $<0.0005^{\mathrm{DL}}$ & $0.0229^{\mathrm{ab}}$ & $139.35 \%$ \\
\hline P3 & $0.0058^{\mathrm{b}}$ & 0.0077 & $<0.0005^{\mathrm{DL}}$ & $0.0202^{\mathrm{ab}}$ & $131.30 \%$ \\
\hline $\mathrm{P} 4$ & $0.0039^{\mathrm{b}}$ & 0.0045 & $<0.0005^{\mathrm{DL}}$ & $0.0149^{\mathrm{ab}}$ & $114.90 \%$ \\
\hline P5 & $0.0039^{b}$ & 0.0065 & $<0.0005^{\mathrm{DL}}$ & $0.0201^{\mathrm{ab}}$ & $168.37 \%$ \\
\hline CONAMA & $0.001 \mathrm{mg} . \mathrm{L}^{-1}$ & & & & \\
\hline $\mathrm{MH}$ & $0.005 \mathrm{mg} . \mathrm{L}^{-1}$ & & & & \\
\hline \multicolumn{6}{|c|}{ Zn } \\
\hline Site & Average & $\begin{array}{l}\text { Standard } \\
\text { deviation }\end{array}$ & Minimum value & Maximum value & RSD \\
\hline P1 & 0.0640 & 0.0644 & 0.0037 & $0.1863^{b}$ & $100.63 \%$ \\
\hline $\mathrm{P} 2$ & 0.0875 & 0.1109 & 0.0109 & $0.3526^{\mathrm{b}}$ & $126.80 \%$ \\
\hline P3 & 0.1027 & 0.1154 & 0.0033 & $0.2825^{\mathrm{b}}$ & $112.30 \%$ \\
\hline $\mathrm{P} 4$ & 0.0900 & 0.0993 & $<0.005$ & $0.2488^{\mathrm{b}}$ & $110.31 \%$ \\
\hline P5 & 0.0902 & 0.0908 & 0.0160 & $0.2994^{\mathrm{b}}$ & $100.69 \%$ \\
\hline CONAMA & $0.18 \mathrm{mg} . \mathrm{L}^{-1}$ & & & & \\
\hline $\mathrm{MH}$ & $5 \mathrm{mg} \cdot \mathrm{L}^{-1}$ & & & & \\
\hline
\end{tabular}

(DL) Values below detection limit of the spectrophotometer; (a) Concentration above CONAMA limit, (b) Concentration above Ministry of Health limit. 
Mean concentrations of $\mathrm{Pb}$ are above the maximum allowed in all sites. At P2 and P3 the maximum concentration of $\mathrm{Pb}$ was about fourteen times higher than the maximum allowed by CONAMA and Ministry of Health, in P4 and P5 there was a reduction of these concentrations, probably due to sampling difficulties during the rainy season (flooding). Note that the water sample collected at site $\mathrm{P} 1$, used by community for consumption, showed average and maximum concentration of $\mathrm{Pb}$ approximately four and ten times higher than allowed by Ministry of Health, respectively (Table 1). This can be seen in Figure 2, which shows Box-plot graphs for $\mathrm{Pb}, \mathrm{Cd}$ and $\mathrm{Zn}$ levels in water samples.

By measuring the relative standard deviation (RSD), note that $\mathrm{Pb}$ showed great variability over time in all sites (Table 1), which can be seen in Figure 2 graphs.

At all sites $\mathrm{Cd}$ concentrations are above the reference values, in $\mathrm{P} 2$ the maximum value was found about twenty times higher than the limit established by CONAMA and five times greater than allowed by Ministry of Health (Table 1). In P2, P3 and P5 it can be seen also high RSD values, indicating greater variability in these sites (Table 1 , Figure 2).

Concentrations of $\mathrm{Zn}$ were below the reference values of Ministry of Health, however the maximum concentrations exceeded CONAMA limits at all sites, almost twice that permitted in P2. The greatest variability was encountered in sites P2, P3 and P4 (Table 1, Figure 2).

In general, all metal concentrations of water samples showed high RSD values and so a great variability in the study period. Over this period, there is also that site P1 had the lowest average concentrations of metals, as well as smaller relative variability (Figure 2).

The descriptive statistics for $\mathrm{Pb}, \mathrm{Cd}$ and $\mathrm{Zn}$ concentrations quantified in sediment samples and Brazilian legislation limits (CONAMA 344) for these metals are shown in Table 2.

All concentrations of metals quantified in sediment samples were found below the limits established by CONAMA at all sites (Table 2).

The highest RSDs for $\mathrm{Cd}$ and $\mathrm{Zn}$ concentrations in P5 and for $\mathrm{Pb}$ concentrations at $\mathrm{P} 3$ indicate greater variability in these sites (Table 2, Figure 3). When comparing the concentrations of metals in sediment and water samples, it is observed that the metals quantified in the sediment showed lower RSD values and thus less variability over time.
Next tables shows descriptive statistics for physicochemical parameters of water samples ( $\mathrm{pH}$ and conductivity, respectively). In Table 3 can be observed descriptive statistics for $\mathrm{pH}$ and the limits of CONAMA 357 and Ministry of Health.

It was found that $\mathrm{pH}$ is within the limit set by CONAMA and Ministry of Health; except in site P1, which reported an average $\mathrm{pH}$ of 5.5 and a minimum of 5 (Table 3 ).

In Figure 4, there are the Box-plot for the physicochemical parameters of water samples, where it is observed that $\mathrm{pH}$ values showed little variability during the study period in almost all sites, except $\mathrm{P} 2$.

In Table 4 can be seen that the electrical conductivity was found to be growing towards upstream-downstream (towards P1 to P5), although there are no legal standards for water quality for this parameter usually values above $100 \mathrm{mS} . \mathrm{cm}^{-1}$ indicate impacted environments (CETESB, 2012). Thus, sites P2, P4 and P5 showed average value of conductivity higher than $100 \mathrm{mS} . \mathrm{cm}^{-1}$, whereas in P4

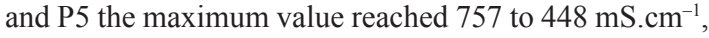
respectively (Table 4, Figure 4 ).

Electrical conductivity showed higher measurements of RSD and therefore greater variability in sites P4 and P5 (Table 4, Figure 4).

Pearson linear correlation between concentrations of quantified metals and time (months) for each site, is shown in Table 5. Through this analysis, it was noted that in water samples, $\mathrm{Pb}$ concentrations showed significant negative correlation at all sites, i.e., the concentration of this metal decreased over time (Table 5 ). The result of run test was also significant $(p<0.05)$, confirming the trend found. In sites P2, P3, P4 and P5 Cd concentrations also showed a significant negative correlation, however the run test indicated randomness in P5 ( $p>0.05)$, therefore, Cd concentrations decreased over time in P2, P3 and P4 (Table 5). For Zn, no significant correlation was observed and the run test indicated randomness $(p>0.05)$, i.e., there wasn't a tendency in their concentrations over time (Table 5).

For sediment samples, only Cd showed significant positive correlation and run test indicated the absence of randomness $(p<0.05)$. Thus, $\mathrm{Cd}$ concentrations increased over time in all sites (Table 5). In contrast $\mathrm{Pb}$ and $\mathrm{Zn}$ concentrations didn't show a tendency over time $(p>0.05)$ (Table 5).
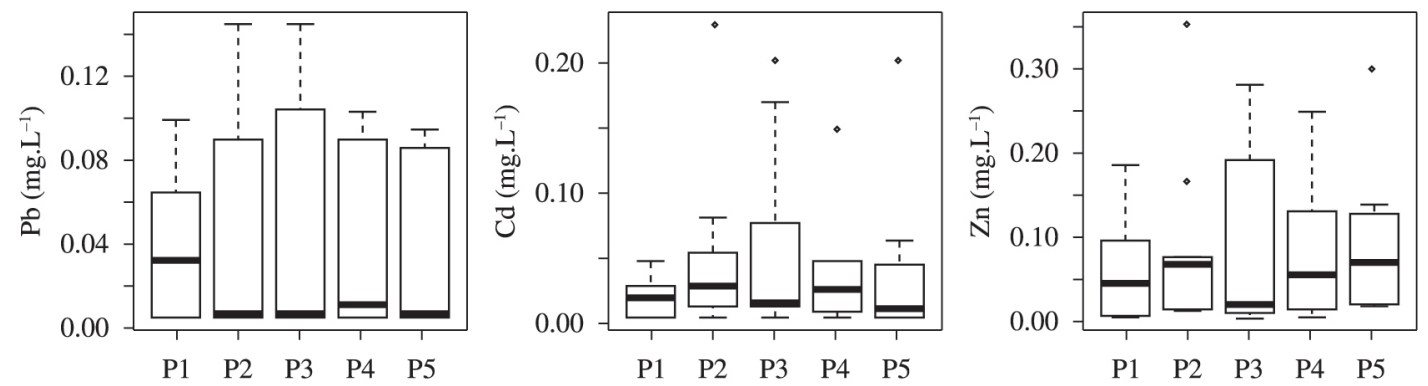

Figure 2. Box-plot graphs for $\mathrm{Pb}, \mathrm{Cd}$ and $\mathrm{Zn}$ levels in water samples. 
Table 2. Descriptive statistics of $\mathrm{Pb}, \mathrm{Cd}$ and $\mathrm{Zn}$ concentrations $\left(\mathrm{mg} \cdot \mathrm{Kg}^{-1}\right)$ in sediment samples for each site. CONAMA limits established by $344 / 2004$ resolution (Level 1) for metals concentrations in sediment.

\begin{tabular}{|c|c|c|c|c|c|}
\hline \multicolumn{6}{|c|}{$\mathbf{P b}$} \\
\hline Site & Average & $\begin{array}{l}\text { Standard } \\
\text { deviation }\end{array}$ & Minimum value & Maximum value & RSD \\
\hline $\mathrm{P} 2$ & 3.7983 & 1.7708 & 0.7713 & 7.4663 & $46.62 \%$ \\
\hline P3 & 3.4163 & 2.0478 & 0.2225 & 6.7350 & $59.94 \%$ \\
\hline $\mathrm{P} 4$ & 3.0590 & 1.2939 & 1.8325 & 5.3813 & $42.30 \%$ \\
\hline P5 & 4.8003 & 1.6435 & 2.6925 & 6.5150 & $34.24 \%$ \\
\hline CONAMA & $35 \mathrm{mg} \cdot \mathrm{Kg}^{-1}$ & & & & \\
\hline \multicolumn{6}{|c|}{ Cd } \\
\hline Site & Average & $\begin{array}{l}\text { Standard } \\
\text { deviation }\end{array}$ & Minimum value & Maximum value & RSD \\
\hline P2 & 0.1556 & 0.0632 & 0.0344 & 0.2238 & $40.62 \%$ \\
\hline P3 & 0.1651 & 0.0568 & 0.0325 & 0.2350 & $34.37 \%$ \\
\hline $\mathrm{P} 4$ & 0.1823 & 0.0507 & 0.0531 & 0.2288 & $27.82 \%$ \\
\hline P5 & 0.1542 & 0.0929 & 0.0181 & 0.2200 & $60.25 \%$ \\
\hline CONAMA & $0.6 \mathrm{mg} \cdot \mathrm{Kg}^{-1}$ & & & & \\
\hline \multicolumn{6}{|c|}{$\mathbf{Z n}$} \\
\hline Site & Average & $\begin{array}{l}\text { Standard } \\
\text { deviation }\end{array}$ & Minimum value & Maximum value & RSD \\
\hline $\mathrm{P} 2$ & 11.7605 & 4.5802 & 4.5450 & 20.9975 & $38.95 \%$ \\
\hline P3 & 9.4783 & 3.3985 & 2.0763 & 15.0850 & $35.86 \%$ \\
\hline P4 & 11.1788 & 5.5020 & 6.8138 & 22.0875 & $49.22 \%$ \\
\hline P5 & 16.8878 & 8.9623 & 7.9613 & 26.7100 & $53.07 \%$ \\
\hline CONAMA & $123 \mathrm{mg} \cdot \mathrm{Kg}^{-1}$ & & & & \\
\hline
\end{tabular}
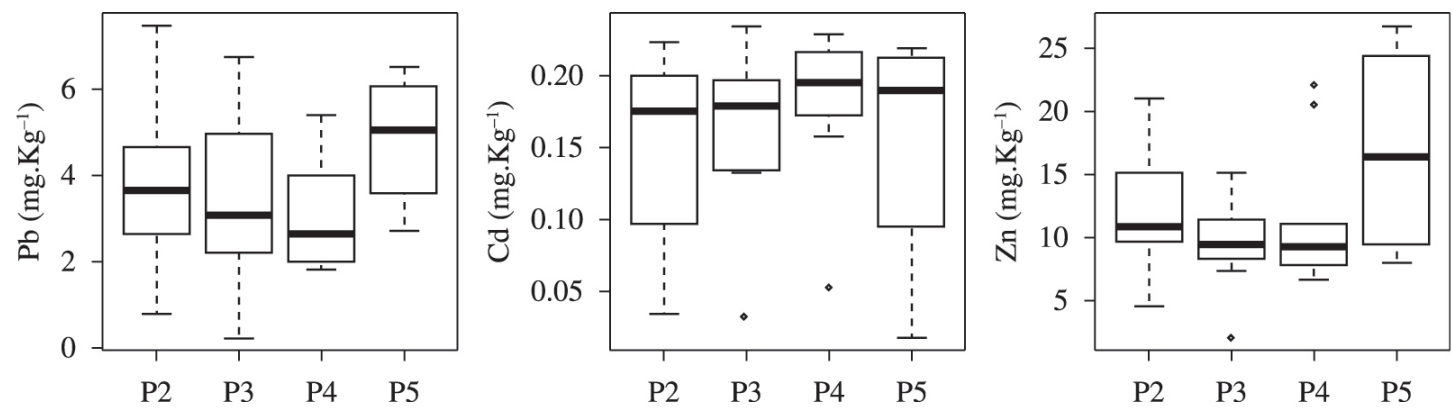

Figure 3. Box-plot graphs for $\mathrm{Pb}, \mathrm{Cd}$ and $\mathrm{Zn}$ levels in sediment samples.

Table 3. Descriptive statistics of water samples $\mathrm{pH}$ at each site. CONAMA limits established by 357/2005 resolution (Class II) and maximum allowable values by decree 2914 of Ministry of Health (MH) for $\mathrm{pH}$ in the water.

\begin{tabular}{cccccc}
\hline Site & Average & $\begin{array}{c}\text { Standard } \\
\text { deviation }\end{array}$ & Minimum value & Maximum value & RSD \\
\hline P1 & $5.53^{\mathrm{ab}}$ & 0.4084 & $5^{\mathrm{ab}}$ & 6.3 & $7.38 \%$ \\
P2 & 6.85 & 0.8449 & 6 & 6.9 & $12.33 \%$ \\
P3 & 6.57 & 0.4057 & 0.1 & 7.4 & $6.17 \%$ \\
P4 & 7.08 & 0.429 & 6.4 & 7.2 & $6.06 \%$ \\
P5 & 6.81 & 0.3479 & 6.1 & & $5.11 \%$ \\
CONAMA & $6.0-9.0$ & & & & \\
MH & $6.0-9.5$ & & & & \\
\hline
\end{tabular}

(a) Value below CONAMA standard; (b) Value below Ministry of Health standard. 

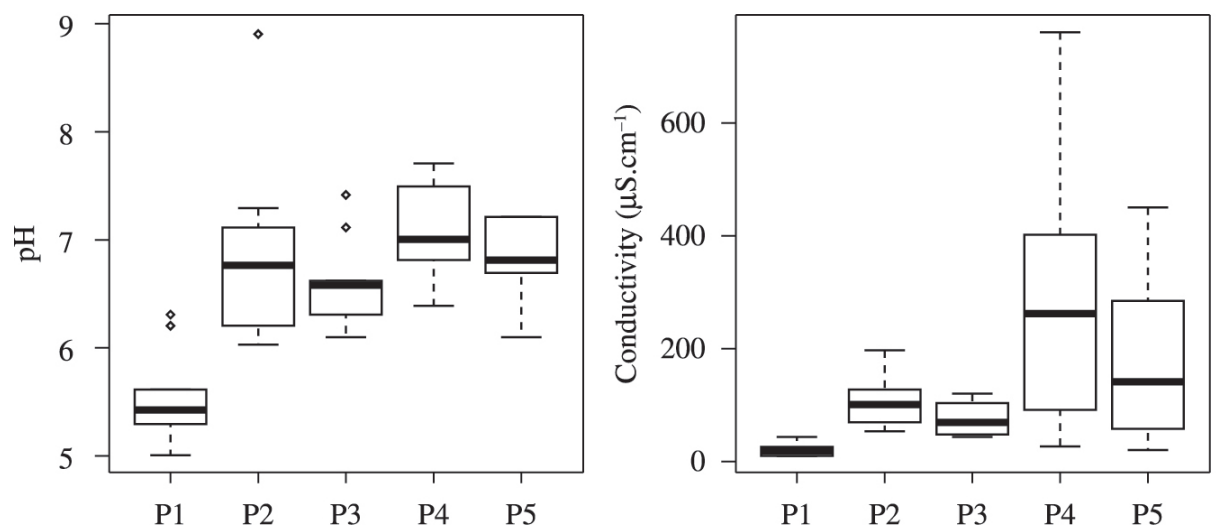

Figure 4. Box-plot graphs for physico-chemical parameters of water samples.

Table 4. Descriptive statistics of water samples conductivity at each site.

\begin{tabular}{cccccc}
\hline Site & Average & $\begin{array}{c}\text { Standard } \\
\text { deviation }\end{array}$ & Minimum value & Maximum value & RSD \\
\hline P1 & 19.42 & 9.98 & 9.88 & 40 & $51.37 \%$ \\
P2 & $102.9^{\mathrm{a}}$ & 43.43 & 54.7 & $200^{\mathrm{a}}$ & $42.22 \%$ \\
P3 & 75.2 & 30.57 & 40.4 & $118.2^{\mathrm{a}}$ & $40.66 \%$ \\
P4 & $308^{\mathrm{a}}$ & 264.46 & 26.5 & $757^{\mathrm{a}}$ & $85.87 \%$ \\
P5 & $170.8^{\mathrm{a}}$ & 140.45 & 18.9 & $448^{\mathrm{a}}$ & $82.22 \%$ \\
\hline
\end{tabular}

(a) Conductivity above $100 \mu \mathrm{S} . \mathrm{cm}^{-1}$ indicates impacted environments (CETESB, 2012).

Table 5. Analysis of Pearson linear correlation between metals concentrations, quantified in water and sediment samples, and time (months) and run test for each site. Pearson linear correlation coefficient (r) and $p$-value of run test.

\begin{tabular}{|c|c|c|c|c|c|}
\hline \multicolumn{6}{|c|}{$\mathbf{P b}$} \\
\hline \multicolumn{3}{|c|}{ Water } & \multicolumn{3}{|c|}{ Sediment } \\
\hline Site & $\mathbf{r}$ & run test & Site & $\mathbf{r}$ & run test \\
\hline P1 & $-0.8458^{s}$ & 0.0128 & & & \\
\hline $\mathrm{P} 2$ & $-0.7539^{s}$ & 0.0128 & $\mathrm{P} 2$ & $-0.1070^{\mathrm{ns}}$ & 0.5023 \\
\hline P3 & $-0.8257^{\mathrm{s}}$ & 0.0143 & P3 & $-0.3279^{\mathrm{ns}}$ & 1.0000 \\
\hline P4 & $-0.8535^{\mathrm{s}}$ & 0.0128 & P4 & $-0.6140^{\mathrm{ns}}$ & 0.1797 \\
\hline P5 & $-0.8117^{\mathrm{s}}$ & 0.0198 & & & \\
\hline \multicolumn{6}{|c|}{ Cd } \\
\hline \multicolumn{3}{|c|}{ Water } & \multicolumn{3}{|c|}{ Sediment } \\
\hline Site & $\mathbf{r}$ & run test & Site & $\mathbf{r}$ & run test \\
\hline P1 & $-0.1487^{\mathrm{ns}}$ & 0.0772 & & & \\
\hline $\mathrm{P} 2$ & $-0.6941^{\mathrm{s}}$ & 0.0128 & $\mathrm{P} 2$ & $0.8332^{\mathrm{s}}$ & 0.0073 \\
\hline P3 & $-0.6878^{s}$ & 0.0128 & P3 & $0.8522^{\mathrm{s}}$ & 0.0073 \\
\hline $\mathrm{P} 4$ & $-0.7844^{\mathrm{s}}$ & 0.0128 & P4 & $0.8322^{\mathrm{s}}$ & 0.0076 \\
\hline P5 & $-0.6398^{\mathrm{s}}$ & 0.2964 & & & \\
\hline \multicolumn{6}{|c|}{ Zn } \\
\hline \multicolumn{3}{|c|}{ Water } & \multicolumn{3}{|c|}{ Sediment } \\
\hline Site & $\mathbf{r}$ & run test & Site & $\mathbf{r}$ & run test \\
\hline $\mathrm{P} 1$ & $-0.6168^{\mathrm{ns}}$ & 0.2964 & & & \\
\hline $\mathrm{P} 2$ & $-0.3173^{\mathrm{ns}}$ & 0.0772 & $\mathrm{P} 2$ & $0.2960^{\mathrm{ns}}$ & 1.0000 \\
\hline P3 & $0.0125^{\mathrm{ns}}$ & 0.4450 & P3 & $-0.4214^{\mathrm{ns}}$ & 0.5023 \\
\hline $\mathrm{P} 4$ & $-0.3303^{\mathrm{ns}}$ & 0.0772 & P4 & $-0.5870^{\mathrm{ns}}$ & 0.1797 \\
\hline P5 & $-0.2229^{\mathrm{ns}}$ & 0.2964 & & & \\
\hline
\end{tabular}

$\left({ }^{\mathrm{s}}\right)$ Correlation significant at $5 \%$ significance level; $\left({ }^{\mathrm{ns}}\right)$ Correlation not significant at $5 \%$ significance level. 


\section{Discussions}

The United States Environment Protection Agency (USEPA) states that besides $\mathrm{Pb}, \mathrm{Cd}$ and $\mathrm{Zn}$, sewage discharges originated in urban areas can contain high concentrations of metals such as $\mathrm{Cu}, \mathrm{Cr}, \mathrm{Ar}, \mathrm{Ni}, \mathrm{Sb}$ and $\mathrm{Se}$, as well as a serial organic pollutant (Rörig et al., 2007). However, metals can also be sourced in surface runoff, given that stormwater carries these contaminants from the urban environment to the drainage catchments, increasing its concentration (Rocha and Martin, 2005; Krissanakriangkrai et al., 2009). In literature were found several studies reporting high concentrations of $\mathrm{Pb}, \mathrm{Cd}$ and $\mathrm{Zn}$ in water and sediment samples taken from water bodies located near urban and industrial regions (Rörig et al., 2007; Peres et al., 2009; Sekabira et al., 2010; Chiba et al., 2011).

Among the results, the highest potential risk to human and environmental health is the high concentration of $\mathrm{Pb}$ found in site P1, whose water is used to free access supply for population. In their interaction with living matter, $\mathrm{Pb}$ affects all organs and body systems. Fundamental biochemical processes are involved in the mechanisms of toxicity of this metal, which include its ability to inhibit or simulate the action of calcium and interact with proteins (Moreira and Moreira, 2004). $\mathrm{Pb}$ toxicity results mainly of their interference with the functioning of cellular membranes and enzymes, forming stable complexes. Disturbances in the function of nervous system and deviations in the heme synthesis are considered critical toxic effects of exposure to $\mathrm{Pb}$ (ATSDR, 2007).

The presence of $\mathrm{Pb}$ in $\mathrm{P} 1$ may be related in part to the low availability of organic matter in site, where the metal could adsorb up and become insoluble. Moreover, P1 has the lowest $\mathrm{pH}$, which favors the dissolution of various metals (Lima et al., 2001).

According to ATSDR (2008), the main anthropogenic sources of $\mathrm{Cd}$ in the environment are: mining nonferrous metals, manufacturing, refining and application of phosphate fertilizers; burning fossil fuels, incineration and waste disposal. Even at low concentrations, $\mathrm{Cd}$ in sediments and water contaminated can accumulate in plants and other organisms and, thus, enter in the food chain (Krissanakriangkrai et al., 2009). Toxic effects of $\mathrm{Cd}$ to human are observed mainly in the kidneys, lungs and bones (ATSDR, 2008).

The chemical element $\mathrm{Zn}$ is essential for living beings because intervenes in the metabolism of proteins and nucleic acids, stimulates the activity of various enzymes and helps in proper functioning of the immune system, e.g. (Urbano et al., 2002). This metal also plays vital role in animal development, and is used as a nutritional supplement to promote growth of higher plants. Although it is an essential element, in high concentrations can be toxic to organisms. In humans and animals can lead to reduced levels of copper, iron function changes and reduction in immune function (Silva et al., 2001).

In sediment samples, Cd was the only metal that showed a rising trend in the time interval studied, corroborating with Huang et al. (2012). The other metals ( $\mathrm{Pb}$ and $\mathrm{Zn}$ ) showed no tendency during the study period. Comparing with CONAMA limits, all metals quantified in sediment remained within permitted by law. This may be due to the stochastic nature of sediment, where changes are generally noticed in longer time (Chiba et al., 2011). So, sediment can be used as an environmental indicator of quality for great time intervals.

The lack of legislation that consider the sediment as an important part in maintaining the environmental quality of aquatic ecosystems, directly affects the importance of studies on this type of sample (Peres et al., 2009). The resolution used as reference in this work treats sediment as waste generated by the dredging activity, which will be arranged in other water bodies or soil (CONAMA, 2004). Therefore, such resolution is more permissive due to wastes presuppose a load of contaminants to be debugged in environmental compartments, and may not provide an estimate of the relevant risk that the water body is exposed.

The release of domestic and industrial effluents on stream probably introduced a great load of organic matter and mineral ions, resulting in high values of electrical conductivity, especially in sites P4 and P5, probably because they add up pollution load of the entire stream. Thus, electrical conductivity indicates that environment is impacted. Similar results were found by Oliveira et al. (2011).

During the study period, $\mathrm{Pb}$ concentrations were decreasing in water samples, suggesting their assimilation by the stream, but remain at unacceptable levels. The sorption of $\mathrm{Pb}$ to the sediment plays a key role in its environmental dynamic and the presence of other metals such as $\mathrm{Cu}$ and $\mathrm{Zn}$ delay its adsorption, while the desorption is a slow process (Bollmann, 2003). So the possible presence of other metals not investigated in water and its stability in the sediment may be the cause of detection of high and low concentrations of $\mathrm{Pb}$ in the respective compartments, at the same time and same collection points (Tables 1 and 2). Much of the existing $\mathrm{Pb}$ in water bodies can be associated with suspended solids from urban surface runoff (Tonietto, 2010).

Concentrations of $\mathrm{Cd}$ decreased in water samples and increased in sediment suggesting therefore the accumulation of this metal in this environmental compartment. The sediments are naturally formed by the precipitation of particles formed in the overlying water column. These suspended particles adsorbs nutrients and contaminants and in sedimentation process transfer them from the water column to the sediment (Czerniawska-Kusza and Kusza, 2011). Soluble forms of Cd can migrate in the water column, while insoluble forms of $\mathrm{Cd}$ can sediment and adsorb to the substrate (ATSDR, 2008). Usually Cd binds strongly to organic matter, which may be fixed for the most part.

Site P1 is not influenced by domestic and industrial effluents and consequently had the lowest concentrations of metals and minor relative variabilities. Sites P2 and P3 showed large variability of metals from sediment and water samples, respectively, as well as Jesus et al. (2004) 
and Miranda et al. (2009). Metals concentrations in water tend to be lower and can oscillate drastically (Saraiva et al., 2009), depending on the water flow or intermittent discharge of effluents. Domestic sewage introduces high organic load and provides a greater amount of nutrients in the water, increasing the biochemical oxygen demand (BOD) (Oliveira et al., 2011). Under these conditions, metals found in polluted water can form chemical complexes that precipitate, reducing its toxicity due to lower availability of these metals dissolved in water (Oliveira et al., 2011).

Site P4 had the highest values of electrical conductivity, possibly due inorganic chlorides present in effluents from textile industries, such as sodium chloride $(\mathrm{NaCl})$ and magnesium $\left(\mathrm{MgCl}_{2}\right)$ used in dyeing and finishing procedures, respectively (IPPC, 2003). Was also observed a large variability of this parameter, which may be related to the carry and leaching of organic matter originating from domestic and industrial effluents (Bernardi et al., 2009).

Finally, site P5 also showed great variability in metals concentrations in the sediment and great variability in electrical conductivity. In addition to accumulate the entire contents of the stream, P5 also receives effluent from the abattoir and the contribution of the confluence with a second stream, accumulating a high load of domestic and industrial effluent. This way, P5 can be considered the site most affected of the study area.

For water bodies classification in environmental laws is necessary that all parameters meet the standards established by them. Although other parameters of the laws still need to be assessed, according to the results obtained in this work, the waters of the stream are not presented in accordance with CONAMA (2005) and Ministry of Health (Brasil, 2011).

\section{Conclusions}

The studied stream shows metals concentrations and physicochemical parameters not in accordance with Brazilian legislation for Class II water bodies.

$\mathrm{Pb}$ concentrations in source stream doesn't agree with standards established by Ministry of Health decree $n^{\circ}$ 2914 , offering risk for population that has free access to supplies. During the study there was transfer of Cd from water column to the sediment.

It's necessary more detailed and continuous monitoring to support strategies for minimize the impact of trace metal contamination and mobilization for decontaminate this environment.

\section{References}

Agency for Toxic Substances and Disease Registry - ATSDR, 2007. Toxicological profile for Lead. Atlanta: Agency for Toxic Substances and Disease Registry.

Agency for Toxic Substances and Disease Registry - ATSDR, 2008. Toxicological profile for Cadmium (Draft for Public Comment). Atlanta: Agency for Toxic Substances and Disease Registry.
ALVIM, LB., KUMMROW, F., BEIJO, LA., LIMA, CAA. and BARBOSA, S., 2011. Avaliação da citogenotoxicidade de efluentes têxteis utilizando Allium cepa L. Ambi-Agua, vol. 6, no. 2, p. 255-265. http://dx.doi.org/10.4136/ambi-agua. 198.

American Public Health Association - APHA, American Water Works Association - AWWA, Water Environment Federation WEF, 2005. Standard methods for the examination of water and wastewater. 21st ed. Washington: APHA. 874 p.

Associação Brasileira de Normas Técnicas - ABNT, 1987. NBR 9898: preservação e técnicas de amostragem de efluentes líquidos e corpos receptors. Rio de Janeiro.

BERNARDI, JVE., LACERDA, LD., DÓREA, JG., LANDIM, PMB., GOMES, JPO., ALMEIDA, R., MANZATTO, AG. and BASTOS, WR., 2009. Aplicação da análise das componentes principais na ordenação dos parâmetros físico-químicos no alto rio madeira e afluentes, Amazônia ocidental. Geochimica Brasiliensis, vol. 23, no. 1, p. 79-90.

BOLLMANN, HA. and MARQUES, DMLM., 2006. Influência da densidade populacional nas relações entre matéria orgânica carbonácea, nitrogênio e fósforo em rios urbanos situados em áreas com baixa cobertura sanitária. Revista Engenharia Sanitária, vol. 11 , no. 4 , p. $343-352$.

BOLLMANN, HA., 2003. Relação da densidade populacional sobre variáveis de qualidade físico-quimica das águas superficiais em microbacias hidrográfica urbanas sem cobertura sanitária em Porto Alegre - RS. Porto Alegre: Universidade Federal do Rio Grande do Sul. 145 p. Tese de Doutorado em Engenharia de Recursos Hídricos e Saneamento Ambiental.

Brasil. Ministério da Saúde, 2011. Portaria $n^{\circ} 2914$, de 12 de Dezembro de 2011. Dispõe sobre os procedimentos de controle e de vigilância da qualidade da água para consumo humano e seu padrão de potabilidade. Diário Oficial da República Federativa do Brasil. Brasília, DF.

CAMPANHA, MB., MELO, CA., MOREIRA, AB., FERRARESE, RFMS., TADINI, AM., GARBIN, EV., BISINOTI, MC. and PEREIRA-FILHO, ER., 2010. Variabilidade espacial e temporal de parâmetros físico-químicos nos rios Turvo, Preto e Grande no estado de São Paulo, Brasil. Quimica Nova, vol. 33, no. 9, p. 1831-1836. http://dx.doi.org/10.1590/S0100-40422010000900002.

CHIBA, WAC., PASSERINI, MD., BAIO, JAF., TORRES, JC. and TUNDISI, JG., 2011. Seasonal study of contamination by metal in water and sediment in a sub-basin in the Southeast of Brazil. Revista Brasileira de Biologia = Brazilian Journal of Biology, vol. 71, no. 4, p. 833-843.

Companhia de Tecnologia de Saneamento Ambiental - CETESB, 2012. Qualidade das águas superficiais no estado de São Paulo 2011. São Paulo: CETESB. 356 p. (Relatórios Ambientais).

Conselho Nacional do Meio Ambiente - CONAMA, 2004. Resolução $n^{\circ}$ 344, de 25 de Março de 2004. Estabelece as diretrizes gerais e os procedimentos mínimos para a avaliação do material a ser dragado em águas jurisdicionais brasileiras, e dá outras providências. Diário Oficial da República Federativa do Brasil. Brasília, DF.

Conselho Nacional do Meio Ambiente - CONAMA, 2005. Resolução $n^{\circ} 357$, de 17 de Março de 2005. Dispõe sobre a classificação dos corpos de água e diretrizes ambientais para o seu enquadramento, bem como estabelece as condições e padrões de lançamento de efluentes, e dá outras providências. Diário Oficial da República Federativa do Brasil. Brasília, DF. 
CZERNIAWSKA-KUSZA, I. and KUSZA, G., 2011. The potential of the Phytotoxkit microbiotest for hazard evaluation of sediments in eutrophic freshwater ecosystems. Environmental Monitoring and Assessment, vol. 179, no. 1-4, p. 113-121. http://dx.doi. org/10.1007/s10661-010-1722-y. PMid:20890787

HUANG, Y., ZHU, W., LE, M. and LU, X., 2012. Temporal and spatial variations of heavy metals in urban riverine sediment: An example of Shenzhen River, Pearl River Delta, China. Quaternary International, vol. 282, p. 145-151. http://dx.doi.org/10.1016/j. quaint.2011.05.026.

Integrated Pollution Prevention and Control - IPPC, 2003. Reference document on best available techniques for the textiles industry. Seville: European Commission.

JESUS, HC., COSTA, EA., MENDONÇA, ASF. and ZANDONADE, E., 2004. Distribuição de metais pesados em sedimentos do sistema estuarino da Ilha de Vitória-ES. Quimica Nova, vol. 27, no. 3, p. 378-386. http://dx.doi.org/10.1590/S0100-40422004000300004.

KRISSANAKRIANGKRAI, O., SUPANPAIBOON, W., JUWA, S., CHAIWONG, S., SWADDIWUDHIPONG, W. and ANDERSON, K.A., 2009. Bioavailable Cadmium in Water, Sediment, and Fish, in a Highly Contaminated Area on the Thai-Myanmay Border. Thammasat International Journal of Science and Technology, vol. 14 , no. 4 , p. $60-68$.

LIMA, MC., GIACOMELLI, MBO., STÜPP, V., ROBERGE, FD. and BARRERA, PB., 2001. Especiação de cobre e chumbo em sedimento do rio Tubarão (SC) pelo método Tessier. Quimica Nova, vol. 24, no. 6, p. 734-742. http://dx.doi.org/10.1590/S010040422001000600005 .

LOPES, DV., 2006. Acúmulo de metais traço cobre (Cu) e zinco (Zn) em viveiros de cultivo de camarão (Litopenaeus vannamei). Fortaleza: Universidade Federal do Ceará. 77 p. Dissertação de Mestrado em Ciências Marinhas Tropicais.

MCGILL, R., TUKEY, J.W. and LARSEN, W.A., 1978. Variations of box plots. The American Statistician, vol. 32, no. 1, p. 12-16.

MIRANDA, RG., PEREIRA, SFP., ALVES, DTV. and OLIVEIRA, GRF., 2009. Qualidade dos recursos hídricos da Amazônia - Rio Tapajós: avaliação de caso em relação aos elementos químicos e parâmetros físico-químicos. Ambi-Agua, vol. 4, n. 2, p. 75-92.

MITTEREGGER-JÚNIOR, H., FERRAZ-DIAS, J., LÚCIAYONEMA, M., ARENZON, A., SILVA, J. and PEGASHENRIQUES, JA., 2006. Avaliação das Atividades Tóxicas e Mutagênicas da Água e do Sedimento do Arroio Estância Velha, Região Coureira-calçadista, Utilizando Allium cepa. Journal of the Brazilian Society of Ecotoxicology, vol. 1, no. 2, p. 147-151. http://dx.doi.org/10.5132/jbse.2006.02.011.

MOREIRA, FR. and MOREIRA, JC., 2004. Os efeitos do chumbo sobre o organismo humano e seu significado para a saúde (Informe especial). Revista Panamericana de Salud Pública, vol. 15, no. 2, p. 119-129. http://dx.doi.org/10.1590/S1020-49892004000200007. PMid:15030657
OLIVEIRA, LM., VOLTOLINI, JC. and BARBÉRIO, A., 2011. Potencial mutagênico dos poluentes na água do rio Paraíba do Sul em Tremembé, SP, Brasil, utilizando o teste Allium cepa. Ambi-Agua, vol. 6, no. 1, p. 90-103. http://dx.doi.org/10.4136/ ambi-agua.176.

PERES, VN., COELHO, LM. and FERREIRA, IM., 2009. Avaliação da qualidade da água superficial da microbacia do córrego Fundo - Catalão (GO). Revista de Ciências Ambientais, vol. 3 , no. 2 , p. $67-85$.

ROCHA, RRA. and MARTIN, ES., 2005. Análise preliminar do estado ambiental do córrego Água da Lavadeira, Rancharia-SP: análise física e química da água. Revista $A G B / T L$, vol. 2, n. 2 , p. $116-130$.

RÖRIG, LR., TUNDISI, JG., SCHETTINI, CA., PEREIRAFILHO, J., MENEZES, JT., ALMEIDA, TC., URBAN, SR., RADETSKI, CM., SPERB, RC., STRAMOSK, CA., MACEDO, RS., CASTRO-SILVA, MA. and PEREZ, JA., 2007. From a water resource to a point pollution source: the daily journey of a coastal urban stream. Revista Brasileira de Biologia = Brazilian Journal of Biology, vol. 67, no. 4, p. 597-609. http://dx.doi.org/10.1590/ S1519-69842007000400003. PMid: 18278310

SANTANA, GP. and BARRONCAS, PSR., 2007. Estudo de metais pesados ( $\mathrm{Co}, \mathrm{Cu}, \mathrm{Fe}, \mathrm{Cr}, \mathrm{Ni}, \mathrm{Mn}, \mathrm{Pb}$ e $\mathrm{Zn})$ na Bacia do TarumãAçu Manaus - (AM). Acta Amazonica, vol. 37, no. 1, p. 111-118.

SARAIVA, VK., NASCIMENTO, MRL., PALMIERI, HEL. and JACOMINO, VMF., 2009. Avaliação da qualidade de sedimentos - estudo de caso: sub-Bacia do ribeirão Espírito Santo, afluente do rio São Francisco. Quimica Nova, vol. 32, no. 8, p. 1995-2002. http://dx.doi.org/10.1590/S0100-40422009000800003.

SEKABIRA, K., ORIGA, HO., BASAMBA, TA., MUTUMBA, G. and KAKUDIDI, E., 2010. Assessment of heavy metal pollution in the urban stream sediments and its tributaries. International Journal of Environmental Science and Technology, vol. 7, no. 3, p. 435-446. http://dx.doi.org/10.1007/BF03326153.

SIEGEL, S. and CASTELLAN, NJ., 1988. Nonparametric statistics for behavioral sciences. 2nd ed. New York: McGraw-Hill. 399 p.

SILVA, AC., VIDAL, M. and PEREIRA, MG., 2001. Impactos ambientais causados pela mineração e beneficiamento de caulim. Revista Escola de Minas, vol. 54, no. 2, p. 133-136. http://dx.doi. org/10.1590/S0370-44672001000200010.

SOUZA, GS., 1998. Introdução aos modelos de regressão linear e não-linear. Brasília: Embrapa-SPI/Embrapa-SEA. 505 p.

TONIETTO, AE., 2010. Especiação de metais e sua interação com a matéria orgânica dissolvida em um reservatório artificial. São Carlos: Universidade Federal de São Carlos. 111 p. Tese de Doutorado em Ciências.

URBANO, MR., VITALLE, MS., JULIANO, Y. and AMANCIO, OM., 2002. Ferro, cobre e zinco em adolescentes no estirão pubertário. Jornal de Pediatria, vol. 78, no. 4, p. 327-334. PMid:14647765. 